\title{
Association of castration-dependent early induction of c-myc expression with a cell proliferation of the ventral prostate gland in rat
}

\author{
Kyu Lim ${ }^{1,4,5}$, Chung Park ${ }^{1}$,Young-Kyoon Kim ${ }^{1}$, \\ Kyung-Ah Yun ${ }^{1}$, Mee-Young Son ${ }^{1}$, \\ Young-Chul Lee ${ }^{1}$, Jong-II Park', \\ Joong-Hwa Lee ${ }^{2}$, Chong-Koo Sul ${ }^{2,4}$, \\ Choong-Sik Lee ${ }^{3}$, Seung-Kiel Park ${ }^{1,3}$ and \\ Byung-Doo Hwang ${ }^{1,3}$ \\ ${ }^{1}$ Department of Biochemistry, College of Medicine, \\ Chungnam National University, Daejeon 301-747, Korea \\ ${ }^{2}$ Department of Urology, College of Medicine, \\ Chungnam National University, Daejeon 301-747, Korea \\ ${ }^{3}$ Department of Pathology, College of Medicine Chungnam National \\ University, Daejeon 301-747, Korea \\ ${ }^{4}$ Cancer Research Institute, Chungnam National University, \\ Daejeon 301-747, Korea \\ ${ }^{5}$ Corresponding author: Tel, +82-42-580-8223; \\ Fax, +82-42-580-8121; E-mail, kyulim@cnu.ac.kr
}

Accepted 7 December 2000

Abbreviations: EDTA, ethylene diamine tetraacetic acid; SDS, sodium dodecyl sulfate; TUNEL, terminal deoxynucleotidyl transferase-mediated dUTP nick end labeling

\begin{abstract}
The protooncogene $c-m y c$ is known to be associated with both cell proliferation and apoptosis. The possible cellular affects of castration on the ventral prostate gland of rat as well as the relationship to a castration induced $c-m y c$ expression were examined. Levels of $c$-myc mRNA in the ventral prostate gland peaked at $6 \mathrm{~h}$ (early induction) and $48 \mathrm{~h}$ (late induction) after castration, respectively. Castrationinduced DNA fragmentation was not observed at an early induction of $c$-myc mRNA. DNA fragmentation appeared to be testosterone-dependent. On the other hand, cellular DNA synthesis measured by $\left[{ }^{3} \mathrm{H}\right]$ thymidine uptake in the ventral prostate gland was increased to maximum at $6 \mathrm{~h}$ after castration. These results suggest that an early induction of $c$-myc mRNA in ventral prostate gland after castration is closely associated with cell proliferation of the gland.
\end{abstract}

Keywords: apoptosis, castration, c-myc, prostate

\section{Introduction}

The prostate gland of an adult male is dependent on androgen for its growth and function. Androgens have effects on prostatic cell proliferation or death (Isaacs, 1984). Testosterone is irreversibly converted via $5 \alpha-$ reductase to dihydrotestosterone within the prostate (Bruchovsky et al., 1968). After castration, the level of prostatic dihydrotestosterone decreases below a critical threshold and the prostate rapidly regresses (Kyprianou et al., 1988; English et al., 1989). Recent studies showed that the involution of the normal prostate gland induced by androgen ablation is an active process involving a cascade of specific biochemical steps that lead to the programmed death of the androgen-dependent glandular epithelial cells (Kerr et al., 1973; Sandford et al., 1984; Kyprianou et al., 1988). Castration-induced death of prostatic epithelial cells is accompanied by specific gene expression, i.e. c-myc (Quamby et al., 1987; Buttyan et al., 1988), p53 (Colombel et al., 1992), and IGFBP (Nickerson et al., 1998). c-Myc protooncogene appears to play an important role in the regulation of cell growth. A transient increase of $c$-myc mRNA occurs during liver regeneration after a partial hepatectomy (Makino et al., 1984) and also has been demonstrated after mitogenic stimulation of quiescent lymphocytes (Kelly et al., 1983). Conversely, c-myc mRNA was increased in the involution of the prostate after castration in rat, and the induction of $c$-myc mRNA was correlated with apoptosis of the ventral prostate (Quamby et al., 1987). Recently, Lee et al. reported that $c$-myc mRNA is transiently induced at the beginning of a period after castration (Lee et al., 1999). In this study, we present a strong evidence that an early induction of $c$-myc mRNA in the ventral prostate after castration may be correlated with proliferation of the ventral prostate.

\section{Materials and Methods}

\begin{abstract}
Materials
Testosterone, agarose, piperazine-N,N'-bis[2-ethanesulfonic acid] (PIPES), 3-[N-morpholino]propanesulfonic acid (MOPS), formaldehyde, formamide, ethidium bromide, phenol, and sodium dodecyl sulfate (SDS) were purchased from Sigma Chemical Co. (St. Louis, MO). Random primed DNA labeling kit, terminal transferase and guanidine thiocyanate were purchased from Boehr-
\end{abstract}


inger Mannheim (Indianapolis, IN). $\alpha-\left[{ }^{32} P\right] d A T P$ (specific activity $3,000 \mathrm{Ci} / \mathrm{mmol}$ ), $\alpha-\left[{ }^{32} \mathrm{P}\right]$ dideoxy-ATP (specific activity $3,000 \mathrm{Ci} / \mathrm{mmol}$ ) and $\left[{ }^{3} \mathrm{H}\right]$ thymidine (specific activity $20 \mathrm{Ci} / \mathrm{mmol}$ ) were purchased from Amersham (Arlington Heights, IL).

\section{Animals and Tissue Preparations}

Male Sprague Dawley rats were obtained from Korea Research Institute of Chemical Technology. Groups of mature rats (350 g body weight) were castrated and in some cases, treated with testosterone propionate (5 $\mathrm{mg} / 0.1 \mathrm{ml}$ in corn oil, s.c.). Tissues were removed immediately after decapitation.

\section{Northern blot hybridization}

Total RNA was prepared by a modification of the method of Karlinsey et al. (Karlinsey et al., 1989). Northern blot hybridization was performed by a modification (Lim et al., 1994) of Virca et al. (Virca et al., 1990) as described. The total RNAs (50 mg) were denatured in formaldehyde and formamide, and fractionated by electrophoresis through a formaldehyde-1.2\% agarose gel. RNA was transferred from the gel to a Nytran ${ }^{\circledR}$ membrane in the presence of $10 \times$ SSC ( $5 \mathrm{M} \mathrm{NaCl}, 0.15 \mathrm{M}$ Na-citrate). After baking at $80^{\circ} \mathrm{C}$ for $1 \mathrm{~h}$, the blotted membrane was prehybridized for $30 \mathrm{~min}$ at $60^{\circ} \mathrm{C}$ in hybridization solution containing $50 \mathrm{mM}$ PIPES, $100 \mathrm{mM}$ $\mathrm{NaCl}, 50 \mathrm{mM}$ sodium phosphate ( $\mathrm{pH} 6.8), 1 \mathrm{mM}$ EDTA, and $5 \%$ SDS. The membrane was hybridized with probe of $1 \times 10^{6} \mathrm{cpm} / \mathrm{ml}$ prepared by a random primed DNA labeling kit. After hybridization for overnight, the blot was rinsed twice with $1 \times$ SSC solution containing $5 \%$ SDS for $15 \mathrm{~min}$ at $60^{\circ} \mathrm{C}$ and followed by autoradiography at $-70^{\circ} \mathrm{C}$ using Kodak X-OMAT AT X-ray film. A Xba I-Bam $\mathrm{HI}$ fragment of pSV-c-myc was used as probe for c-myc (Land et al., 1983). Two separate experiments were performed repeatedly.

\section{Determination of DNA synthesis}

$\left[{ }^{3} \mathrm{H}\right]$ Thymidine (specific activity; $20 \mathrm{Ci} / \mathrm{mmol}$, New England Nuclear) was used to evaluate DNA synthesis. After castration, the rats were injected intraperitoneally with $\left[{ }^{3} \mathrm{H}\right]$ thymidine $(20 \mu \mathrm{Ci} / 100 \mathrm{~g}$ of body weight in 0.4 $\mathrm{ml}$ of sterile saline) and DNA synthesis was assayed by a modification (Lim et al., 1993) of the method of the Barbiroli et al. (Barbiroli et al., 1971).

\section{DNA extraction and apoptotic DNA fragmentation}

Total DNA was isolated from frozen tissue (Tilly et al., 1993) and quantitated by absorbance at $260 \mathrm{~nm}$. One microgram of DNA from each sample was labeled at 3'ends using $\left[\alpha^{-32} \mathrm{P}\right]$ dideoxy-ATP $(3,000 \mathrm{Ci} / \mathrm{mmol}$; Amersham Arlington Heights, IL) by terminal transferase enzyme (Boehringer-Mannheim, Indianapolis, IN) with modification (Cha et al., 2000) as described (Tilly et al.,
1993). The labeled DNA samples (200 ng/lane) were loaded onto $2 \%$ agarose gel and separated by electrophoresis at $50 \mathrm{~V}$. The gels were dried in a slab-gel dryer without heat and exposed to X-ray films for qualitative analysis. After autoradiography, the amount of radiolabeled dideoxy-ATP incorporated into low molecular weight $(<20 \mathrm{~kb})$ DNA fractions can also be quantitated by cutting the respective fraction of DNA from the dried gel and counting in a liquid scintillation counter. The amount of $\left[\alpha_{-}{ }^{32} \mathrm{P}\right]$-dideoxy-ATP incorporated into the low molecular weight DNA fractions per nanogram of DNA labeled was used as a quantitative estimation of the degree of apoptotic DNA fragmentation within various samples.

\section{TUNEL assay}

Apoptotic bodies were detected in formalin-fixed, paraffin embedded tissue sections using the ApoTag ${ }^{\circledR}$ Peroxidase in situ apoptosis detection kit (Intergen Co., NY) which is based on the terminal deoxynucleotidyl transferase-mediated dUTP nick end labelling (TUNEL) method. Five micromolar sections were prepared and treated according to the manufacturers instructions. Apoptotic bodies were visualized and photographed under an inverted microscope.

\section{Results}

Differential expression of c-myc mRNA after castration in the ventral prostate

We have previously reported that protooncogene c-myc is differentially regulated in the ventral prostate after castration (Lee et al., 1999). To confirm a castrationdependent induction of $c$-myc mRNA, total RNAs were prepared from the ventral prostate. The presence of $c$ myc mRNA was detected by Northern blot hybridization using the third exon of the human c-myc gene as a probe. As a control, sham operation was used. In the ventral prostate, levels of $c$-myc mRNA increased to an approximately 10 fold at $6 \mathrm{~h}, 3$ fold at $24 \mathrm{~h}$ and 9 fold at $48 \mathrm{~h}$ after castration, respectively (Figure 1). The membranes used for detection of $c$-myc mRNA were also washed and rehybridized to cDNA probes for the major androgen-dependent secretory protein (C1 subunit for prostatic binding protein) and androgenrepressed protein (TRPM-2) of the rat ventral prostate. C1 mRNA was gradually repressed and TRPM-2 mRNA was induced at $48 \mathrm{~h}$ after castration. These results suggest that $c$-myc gene is differentially regulated in the ventral prostate after castration.

Early induction of c-myc mRNA after castration is not related to apoptotic DNA fragmentation

Late induction of $c-m y c$ mRNA may play a role in the 


\section{Time after Castration}

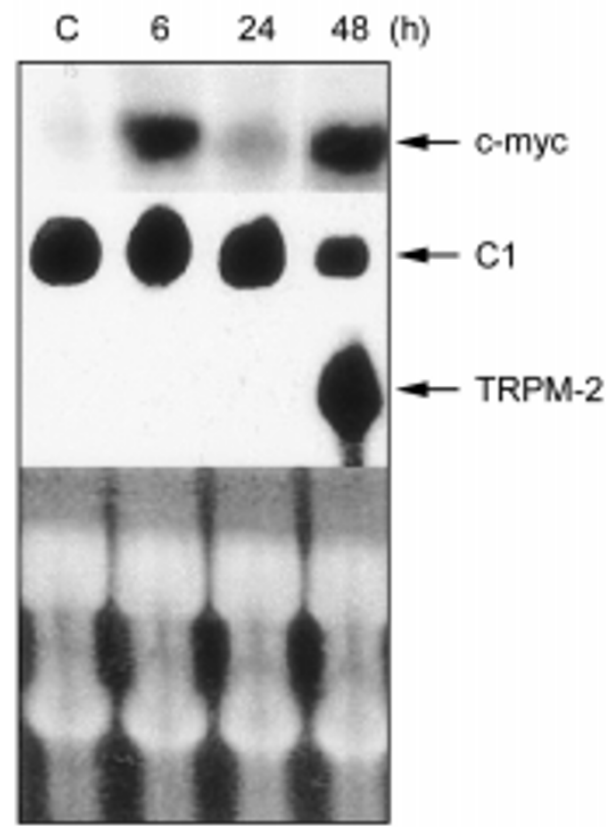

Figure 1. Time course of the castration-dependent change of $c$-myc in the ventral prostate. At the indicated time, the ventral prostate was removed from groups of rats which were either sham-operated (control) or castrated, and total RNA was prepared. Total RNA $(50 \mu \mathrm{g})$ was analyzed by Northern blot hybridization using a c-myc cDNA probe as described in 'Materials and Methods'.

epithelial cell regression and apoptosis was seen in the ventral prostate after androgen withdrawal (Quamby et al., 1987). To investigate whether an early induction of c-myc mRNA is related to apoptosis, DNA fragmentation was assayed. Analysis of DNA fragmentation of the ventral prostate using 3'-end labeling with terminal transferase indicated that the ventral prostate of intact rat contained predominantly high molecular weight DNA. Castration increased DNA cleavage into low molecular weight fragment of $185 \mathrm{bp}$ multiples in a time-dependent manner with a detectable increase at 1 day and a maximal increase at 5 days after castration. As in the intact rats, the ventral prostate from an early phase $(6 \mathrm{~h})$ after castration did not exhibit apoptotic DNA fragmentation (Figure 2), thus ruling out the possibility that the operation procedure itself causes apoptotic cell death. TUNEL assays were also performed on the ventral prostate sections in order to confirm the correlation between DNA fragmentation and apoptotic body at the various time points after castration. In sham control and $6 \mathrm{~h}$ following castration, apoptotic body was not detected in the ventral prostate. By $24 \mathrm{~h}$, a small number of cells were apoptotic and a number of apoptotic cells were rapidly increased by $48 \mathrm{~h}$ following castration in the ventral prostate (Figure 3 ). Therefore, the early induction of $c-m y c$ mRNA is not related to apoptotic DNA fragmentation. It is known that cast-
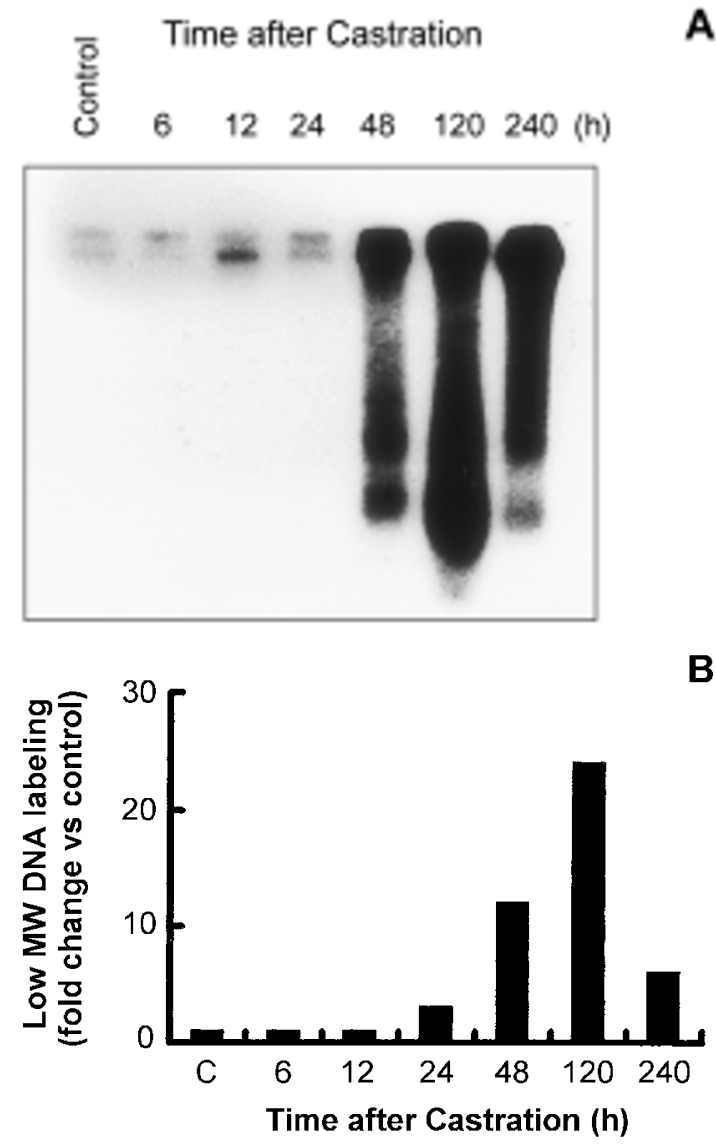

C

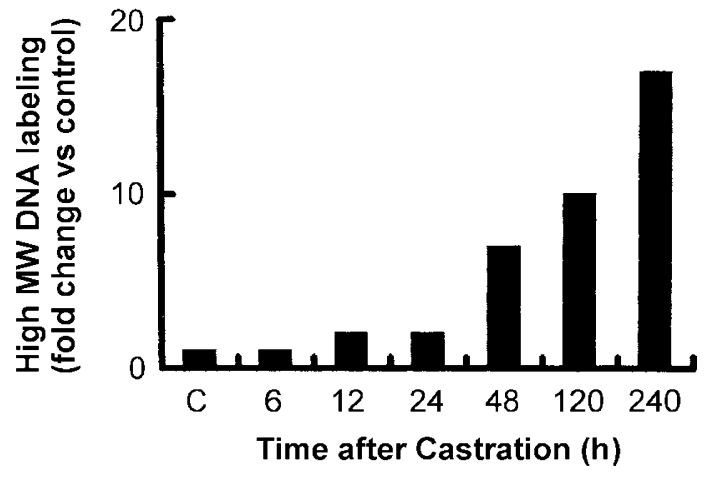

Figure 2. Castration-induced DNA fragmentation in the ventral prostate. At the indicated time, the ventral prostate was labeled on 3'-ends with- ${ }^{32}$ Pdideoxy-ATP, and analyzed by electrophoresis in $2 \%$ agarose gel. Autoradiography $(A)$ and followed by $\beta$-counting of low molecular weight ( $\leq 15 \mathrm{~kb}, \mathrm{~B})$ and high molecular weight $(\geq 15 \mathrm{~kb}, \mathrm{C})$ DNA fractions. The amounts of $\alpha-{ }^{32}$ P]dideoxy-ATP incorporated into DNA fractions from different groups were compared with that of intact animals at each time point.

ration-dependent apoptosis of the ventral prostate is related to androgen withdrawal (English et al., 1989; Kyprianou and Isaacs, 1998). To identify whether testosterone suppresses apoptotic DNA fragmentation, testosterone was injected after castration. Treatment 

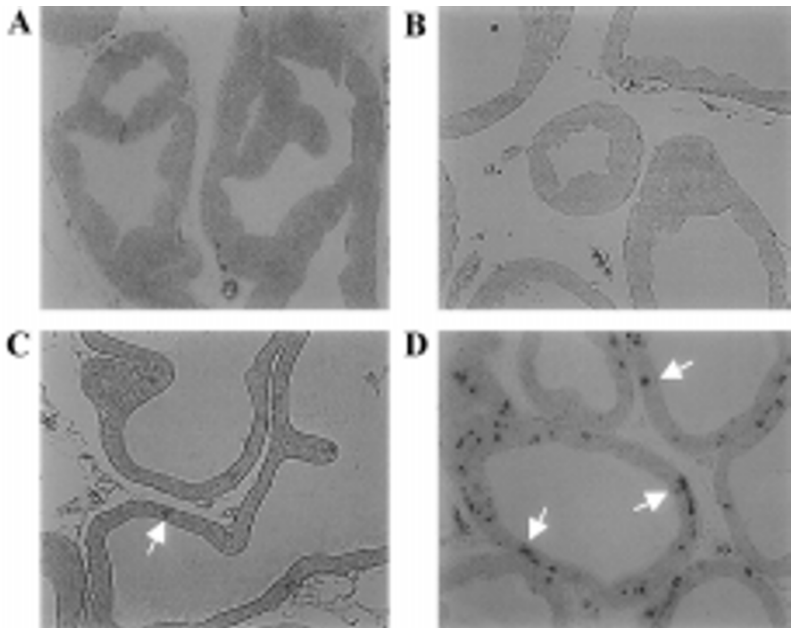

Figure 3. TUNEL assay in the ventral prostate following castration. The TUNEL method was used to detect apoptotic cells in situ in formalinfixed, paraffin embedded sections of ventral prostate tissue. Results from an assay including ventral prostate tissue from sham-operated rat (A), $6 \mathrm{~h}$ (B), $24 \mathrm{~h}$ (C) and $48 \mathrm{~h}$ (D) after castration are shown. The other assays were performed as described in 'Materials and Methods'. Magnification $\times 200$.

with testosterone almost blocked castration-induced apoptotic DNA cleavage (Figure 4). The result suggests that the castration-dependent apoptotic DNA cleavage is likely caused by testosterone withdrawal.

\section{Castration-dependent early induction of $c$-myc mRNA is correlated with DNA synthesis in the ventral pro- state}

It is known that the expression of $c$-myc is enhanced during the androgen-induced proliferation and regrowth of the involuted prostate (Furuya and Isaacs, 1993). To investigate a biological function of an early induction of c-myc mRNA after castration, DNA synthesis was determined using $\left[{ }^{3} \mathrm{H}\right]$ thymidine. After castration, DNA synthesis rapidly increased and then reached to a peak at $6 \mathrm{~h}$. Subsequently, the DNA synthesis gradually decreased (Figure 5).

\section{Discussion}

Apoptosis is a gene-directed process and can be seen, along with more familiar gene-directed process like differentiation, as a part of the repertoire available to the cellular response to external and internal stimuli. c-Myc is a very important element in cell proliferation, but it is continuously present under conditions of growth arrest, such as growth factor deprivation, which can induce apoptosis (Bissonnette et al., 1994). In addition, c-myc antisense oligonucleotides inhibit the activation-induced cell death of T cell hybridoma (Shi et al., 1992), sug-

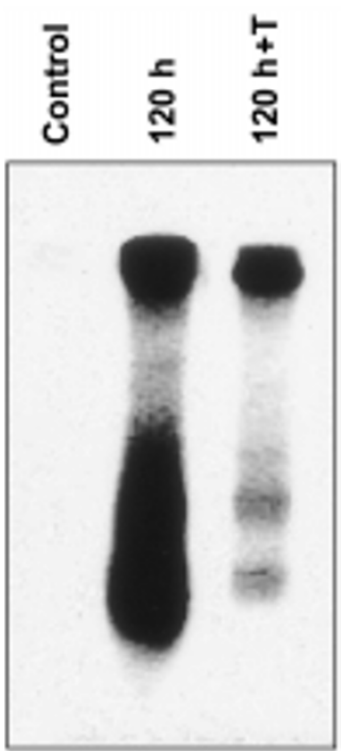

Figure 4. Effect of testosterone on castration-induced DNA fragmentation in the ventral prostate. Testosterone propionate $(5 \mathrm{mg})$ was administered immediately after castration. The other assays were performed as described in Figure 2.

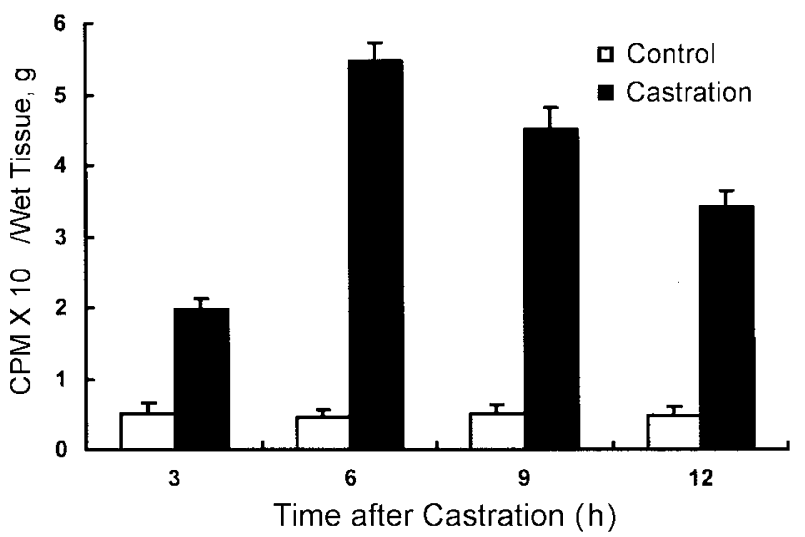

Figure 5. Incorporation of radiolabeled thymidine into the ventral prostate after castration. Rats were intraperitoneally injected with ${ }^{3}$ Hthymidine $(20$ $\mu \mathrm{Ci} / 100 \mathrm{~g}$ of body weigth in $0.4 \mathrm{ml}$ of sterile saline) and pulsed for $2 \mathrm{~h}$. Rats were killed at each time indicated in the Figure. The total uptake expressed as count per minute $\left(\times 10^{4}\right)$ per $g$ of the ventral prostate is shown. The other assays were performed as described in Materials and Methods. The results represent the mean of triplicate samples from three separate experiments.

gesting that expression of endogenous $c-m y c$ is required for an induction of apoptosis in this situation. c-Myc can therefore induce both proliferation and apoptosis, and the cellular decision between these two responses is determined by other signals, such as the presence of growth factors or other survival stimuli. Androgen ablation-induced prostatic cell death involves a genetically programmed series of events, which are initiated when prostatic androgen decreases beyond a critical point (Fruya and Isaacs, 1993). c-Myc mRNA is also increased during prostatic glandular cell proliferation by an 
androgen treatment after castration and gradually decreased. In our experiments, c-myc mRNA was differentially induced and reached a maximum level at 6 hours and $48 \mathrm{~h}$, respectively. Therefore castrationdependent early induction of $c-m y c$ mRNA may be related to a partial decrease of dihydrotestosterone concentration in the ventral prostate after castration.

Apoptotic cells are infrequently observed in the ventral prostate of intact rat. There is no change in the percentage of apoptotic epithelial cells, whereas apoptotic bodies are strikingly apparent on day 2 following castration (English et al., 1989). On the other hand, Nickerson et al. reported that apoptosis in the ventral prostate, as detected in situ by the TUNEL method, was also induced as early as $6 \mathrm{~h}$ after castration (Nickerson et al., 1998). In the present data, apoptotic body and DNA fragmentation were not entirely detected at $6 \mathrm{~h}$ after castration. The result was quite different from the report of Nickerson et al., which apoptotic DNA fragmentation and apoptotic body were detected at $6 \mathrm{~h}$ in the ventral prostate after castration and they were exhibited at $24 \mathrm{~h}$ and rapidly increased at $48 \mathrm{~h}$ (1998). Therefore the apoptosis of the ventral prostate is closely correlated only with a late $c-m y c$ induction and is androgendependent. c-Myc is induced by a two-way state in cells that the cell chooses either apoptosis or proliferation, depending on the presence or absence of second "survival" signals such as growth factors (Bissonnette et al., 1994). However, an early induction of $c$-myc mRNA in the ventral prostate after castration is not related to apoptosis. In summary, protooncogene c-myc is differentially regulated in the ventral prostate after castration, and an early induction of $c$-myc mRNA is related to proliferation of the ventral prostate, whereas a late induction is related to apoptotic DNA fragmentation. The physiological significance of an early induction of $c$-myc mRNA in the ventral prostate after castration is not known as yet.

\section{Acknowledgement}

We thank Dr. R.A. Weinberg for pSV-c-myc, Dr. R.J. Matusik for $\mathrm{pC} 1$ and Dr. M. Tenniswood for TRPM-2. This work was partially supported by a Grant (951-0709032-1) from the Korea Science and Engineering Foundation (KOSEF) in Korea.

\section{References}

Barbiroli, B. and Porter, V. R. (1971) DNA synthesis and interaction between controlled feeding schedules and partial hepatectomy in rats. Science 172: 738-741

Bissonnette, R. P., Shi, Y., Mahboubi, J. M. and Green, D. R.
(1994) c-Myc and apoptosis. In Apoptosis II (Tomei, L.D., and Cope, R.O., eds), pp327-356, CSHL Press, New York

Bruchovsky, N. and Wilson, J. D. (1968) The intranuclear binding of testosterone and $5 \alpha$-androstan-17 $\beta$-ol-3-one by rat prostate. J. Biol. Chem. 243: 5953

Buttyan, R., Zakeri, Z., Lockshin, R. and Wolgemuth, P. (1988) Cascade induction of c-fos, c-myc, and heat shock $70 \mathrm{k}$ transcripts during regression of the rat ventral prostate gland. Mol. Endocrinol. 2: 650-657

Cha, S. C., Suh, K. S., Song, K. S. and Lim, K. (2000) Cell death in retinoblastoma: Electron microscopic, immunohistochemical, and DNA fragmentation studies. Ultrastruct. Pathol. 24: 23-32

Colombel, M., Olsson, C. A., Ng, P. Y. and Buttyan, R. (1992) Hormone-regulated apoptosis results from reentry of differentiated prostate cells onto a defective cell cycle. Cancer Res. 52: 4313-4319

English, H. F., Kyprianou, N. and Isaacs, J. T. (1989) Relationship between DNA fragmentation and apoptosis in the programmed cell death in the rat prostate following castration. Prostate 15: 233-250

Furuya, Y. and Isaacs, J. Y. (1993) Differential gene regulation during programmed death (apoptosis) versus proliferation of prostatic glandular cells induced by androgen manipulation. Endocrinology 133: 2660-2666

Isaacs, J. T. (1984) Antagonistic effect of androgen on prostatic cell death. Prostate 5: 545-557

Karlinsey, J., Stamatoyannopoulus, G. and Envr, T. (1989) Simultaneous purification of DNA and RNA from small number of eukaryotic cells. Anal. Biochem. 180: 303-306

Kelly, K., Cochran, B., Stiles, C. D. and Leder, P. (1983) Cell specific regulation of the $c$-myc gene by lymphocyte mitogens and platelet derived growth factor. Cell 35: 303-610

Kerr, J. F. R. and Searle, J. (1973) Deletion of cells by apoptosis during castration-induced involution of the rat prostate. Virchows Arch. [Cell Pathol.] 13: 87-102

Kyprianou, N. and Isaacs, J. T. (1988) Activation of programmed cell death in the rat ventral prostate after castration. Endocrinology 122: 552-562

Kyprianou, N. and Isaacs, J. T. (1988) Activation of programmed cell death in the rat ventral prostate after castration. Endocrinology 122: 552-562

Land, H., Parada, L. F. and Weinber, R. A. (1983) Tumorigenic conversion of primary embryo fibroblasts requires at least two cooperating oncogenes. Nature 304: 596-602

Lee, J. H., Sul, C. K., Kim, Y. K., Hwang, B. D. and Lim, K. (1999) Differential regulation of protooncogene c-myc expression in rat ventral prostate after castration. Biochem. Mol. Biol. Int. 47: 143-151

Lim, K., Park, H. C., Kim, K. Y., Lee, M. S., Kweon, G. R., Kwak, S. T. and Hwang, B. D. (1993) Regenerating liverspecific transacting factors of $\mathrm{H} 2 \mathrm{~B}$ histone gene are newly synthesized during liver regeneration. Biochem. Biophys. Res. Comm. 196: 1093-1100 
Lim, K., Yoo, J. H., Kim, K. Y., Kweon, G. R., Kwak, S. T. and Hwang, B. D. (1994) Testosterone regulation of proto-oncogene c-myc expression in primary Sertoli cell cultures from prepubertal rats. J. Androl. 15: 543-550

Makino, R., Hayashi, K. and Sugimura, T. (1984) C-myc transcript is induced in rat liver at a very early stage of regeneration or by cycloheximide treatment. Nature 310: 697-699

Nickerson, T., Pollak, M. and Huynh, H. (1998) Castrationinduced apoptosis in the rat ventral prostate is associated with increased expression of genes encoding insulin-like growth factor binding proteins 2, 3, 4 and 5. Endocrinology 139: 807810

Quamby, V. E., Beckmann, W. C., Wilson, E. M. and French, F. S. (1987) Androgen regulation of c-myc messenger ribonucleic acid levels in rat ventral prostate. Mol. Endocrinology 1: 864-874
Sandford, N. L., Searle, J. W. and Kerr, J. F. K. (1984) Successive waves of apoptosis in the rat prostate after repeated withdrawal of testosterone stimulation. Pathology 16: 406-410

Shi, Y. Glynn, J. M., Guilbert, L. J. H., Cotter, T. G., Bisonette, R. P. and Green D. R. (1992) Role for c-myc in activationinduced apoptotic cell death in T-cell hybridoma. Science 257: 212-214

Tilly, J. L. and Hsueh, A. J. W. (1993) Microscale autoradiographic method for the qualitative and quantitative analysis of apoptotic DNA fragmentation. J. Cell Physiol. 154: 519-526

Virca, G. D., Norhemann, W., Shiels, B. R., Widera, G. and Broome, S. (1990) Simplified northern blot hybridization using $5 \%$ sodium dodecyl sulfate. BioTechniques $8: 370-372$ 